\title{
Healing Ministry Pada Masa Pandemi Covid 19 Sebagai Salah Satu Bentuk Pelayanan Pastoral Gereja Yang Mendesak di Indonesia Pada Masa Kini
}

\author{
Apolos Dwi Kristantyo \\ Sekolah Tinggi Teologi Sriwijaya \\ apolos2018@gmail.com
}

\begin{abstract}
This article aims to describe the healing ministry as a form of urgent pastoral care during the Covid 19 pandemic. This search aims to find concepts or forms of healing ministry in the Bible and the thoughts of the scholars about church healing services. That since the beginning of 2020 until now, many people have been exposed to the covid 19 virus, making them sick, difficult and suffering. This situation calls the church to perform healing ministries.
\end{abstract}

Keywords: healing ministry, recovery, sick, difficulty, suffering

Abstrak: Artikel ini bertujuan untuk menggambarkan tentang healing ministry atau pelayanan kesembuhan sebagai salah satu bentuk pelayanan pastoral yang mendesak pada masa pandemi Covid 19. Penelusuran ini bertujuan untuk menemukan konsep atau bentuk-bentuk pelayanan kesembuhan dalam Alkitab dan pemikiran-pemikiran para ahli tentang pelayanan kesembuhan gereja. Bahwa sejak awal tahun 2000 hingga kini, banyak masyarat yang telah terpapar viruis covid 19, sehingga sakit, susah dan menderita. Keadaan yang demikian ini memanggil gereja untuk melakukan pelayanan kesembuhan.

Kata kunci: healing ministry, kesembuhan, sakit, kesusahan, menderita

Article History

\begin{tabular}{|l|l|l|}
\hline Submitted: 11 Juni 2020 & Revised: 30 Juli 2021 & Accepted: 30 Juli 2021 \\
\hline
\end{tabular}

\section{PENDAHULUAN}

Diskusi atau perbincangan tentang pelayanan kepada orang sakit atau healing ministry bukanlah topik yang baru, tetapi bukan berarti usang. Karena pada dasarnya para ahli sudah sejak lama dan sudah banyak yang membahas atau membicarakannya. Dalam hal ini, J. L. CH. Abineno sendiri pernah mengatakan telah menerima begitu banyak permintaan agar menulis suatu karangan pendek tentang pelayanan pastoral kepada orang-orang sakit. Dan beliau sendiri memiliki kerinduan untuk menulis suatu karangan yang lebih panjang tentang pokok ini (Abineno, 1994). Ahli yang lain, Totok $\mathrm{S}$. Wiryasaputra juga sudah menulis buku tentang pendampingan pastoral orang sakit (Wiryasaputra, 2016). Itu artinya, kebutuhan pelayanan kepada orang sakit atau pelayanan kesembuhan pada masa pandemi covid 19 sebagai salah satu bentuk pelayanan pastoral gereja di Indonesia pada masa kini adalah kebutuhan pelayanan yang mendesak untuk dilakukan, baik oleh gereja atau masyarakat pada umumnya. 
Kita tentu bersetuju dengan pendapat yang mengatakan bahwa gereja harus secara terus menerus menemukan cara yang segar untuk memenuhi kebutuhan orang susah, khususnya orang-orang yang sedang sakit secara fisik. Jika tidak, gereja tentu sudah tidak dapat memenuhi kebutuhan-kebutuhan warga jemaatnya atau masyarakat di sekitar. Seperti kita tahu bahwa di sekitar kita masih banyak orang susah dan menderita, yang disebabkan oleh paparan virus corona (covid 19), yang sudah masuk Indonesia sejak Senin 2 Maret 2020 (Detiknews, 2020). Sejauh ini, masyarakat Indonesia yang sudah terpapar covid 19 per 28 Juli 2021 adalah 3.287.727 dan yang dinyatakan sembuh 2. 640.676 (Detiknews, 2021). Itu artinya ada begitu banyak orang yang sakit, susah dan menderita. Mereka membutuhkan pelayanan kesembuhan.

Dalam hal ini, apakah gereja sudah melakukan perannya? Apakah gereja sudah melakukan pelayanan kesembuhan bagi mereka yang sedang sakit, susah dan menderita? Pada saat ini gereja dipanggil untuk melakukan tugasnya, yaitu melayani mereka yang sedang sakit, susah dan menderita karena covid 19. Artinya, sebagaimana pendapat Howard Clinebell, gereja harus menjadi saluran baru untuk pelayanan di sepanjang zaman (Clinebel, 2006). Karena dengan demikian gereja dapat tetap relevan bagi kebutuhan orang. Gereja memang dipanggil untuk menggumuli bentuk-bentuk pelayanan yang dapat memenuhi atau menjawab kebutuhan-kebutuhan jemaat yang memang sedang sakit, susah dan menderita. Menurut Clinebell, metode pendampingan dan konseling pastoral memberi/menawarkan saluran penyembuhan dan pertumbuhan yang luas dalam periode sejarah gereja dewasa ini (Clinebel, 2006).

Memang dengan pergumulan-pergumulan yang khusus ini, sebenarnya sudah muncul pemikiran-pemikiran yang ideal tentang pelayanan pastoral, yaitu: pelayanan pastoral di dalam jemaat (Clinebel, 2006), pelayanan pastoral kepada orang sakit atau bagi orang sakit (Daniel Susanto, 2003), pelayanan pastoral bagi penderita HIV/AID (Daniel Susanto, 2003), dll. Tetapi pada kenyataannya masih banyak gereja yang belum bertindak kontinu atas jemaat-jemaat yang sedang sakit, susah dan menderita karena penyakit yang dirasakannya dan sakit permanen yang dideritanya. Kebanyakan gereja baru memberikan layanan diakonia spontan terhadap jemaat yang sakit, susah dan menderita, yaitu melalui kunjungan, doa dan pemberian dana untuk berobat.

Artikel ini dibuat dalam rangka ikut memberikan pemikiran tentang pelayanan kesembuhan atau healing ministry gereja. Dalam hal ini menemukan konsep atau bentuk-bentuk pelayanan kesembuhan dalam Alkitab dan pemikiran-pemikiran para 
ahli tentang pelayanan kesembuhan gereja. Karena tidak dapat dipungkiri bahwa sejak awal tahun 2000 hingga kini, banyak masyarakat yang telah terpapar virus covid 19, sehingga sakit, susah dan menderita. Keadaan yang demikian ini memanggil gereja untuk melakukan pelayanan kesembuhan.

\section{METODE PENELITIAN}

Dalam penelitian ini penulis akan menggunakan metode literatur dengan mengumpulkan sumber literatur yang terkait dengan healing ministry. Kemudian penulis akan menghubungkan healing ministry dalam konteks pademi covid 19 yang sedang terjadi saat penulisan karya ilmiah ini.

\section{HASIL DAN PEMBAHASAN}

\section{Pelayanan Kesembuhan di Dalam Alkitab}

Di dalam Alkitab kita tentu dapat menemukan praktek pelayanan kesembuhan yang dilakukan umat Tuhan, khususnya para Nabi dan Imam terhadap orang-orang yang sakit dan susah. Karena itu dalam artikel ini akan dilihat secara khusus bagaimana praktek pelayanan kesembuhan di dalam Perjanjian Lama (PL) dan Perjanjian Baru (PB). Dengan demikian kita dapat belajar dan memahami pentingnya sebuah pelayanan kesembuhan bagi mereka yang sakit.

\section{Pelayanan Kesembuhan di Dalam Perjanjian Lama}

Di dalam Perjanjian Lama ada banyak cerita mujizat, yaitu kisah bagaimana orang-orang yang mengalami sakit-penyakit telah disembuhkan oleh Allah melalui pelayanan para Nabi, seperti Musa (Bil. 12), Elia (1 Raj. 17:17-24), Elisa (2 Raj.4:138; 5:1-17), dll. Karena itu kita dapat mempelajari secara rinci bagaimana praktek pelayanan kesembuhan yang para nabi lakukan.

\section{a. Pelayanan Kesembuhan Musa}

Musa adalah seorang nabi, yang dipanggil dan diutus oleh Allah untuk membawa bangsa Israel ke luar dari tanah Mesir menuju tanah Kanaan (Kel. 3:8-10). Pada awalnya Musa merasa keberatan untuk menerima panggilan ini dan bermaksud ingin menolaknya. Tetapi pada akhirnya, ia pun menerima tugas pengutusan untuk membawa bangsa Israel keluar dari tanah Mesir menuju tanah Kanaan.

Dalam perjalanan mereka menuju tanah Kanaan, ketika mereka berada di antara Hazerot - padang gurun Aran, terjadi suatu peristiwa di mana Miryam dan Harun mengata-ngatai Musa berkenaan dengan perempuan Kush yang diambilnya 
(Bil. 12:1). Atas peristiwa ini, Allah menjadi murka, sehingga Miryam terkena kusta (ayat 9-10).

Tetapi, Harun memohon kepada Musa agar mereka mendapat belas kasihan atas dosa-dosa mereka, sehingga mereka tidak ditimpa suatu hukuman atau penyakit atas kebodohan mereka (ayat 11-12). Karena itu, berserulah Musa kepada Tuhan : "Ya Allah, sembuhkanlah kiranya dia" (ayat 13). Dan setelah tujuh hari dalam pengucilan, Miryam sembuh dan diterima kembali, sehingga mereka dapat melanjutkan perjalanan mereka (ayat 14-15).

Di dalam pelayanan kesembuhan yang dilakukan Musa terhadap saudaranya, yaitu Miryam, yang dilakukannya adalah berseru atau berdoa kepada Tuhan. Dari sini, kita dapat belajar bahwa berseru atau berdoa adalah tindakan yang penting dan mendasar bagi pelayanan kesembuhan. Melalui doa, Tuhan yang berkuasa menyembuhkan akan menyatakan kuasa-Nya. Dan kesembuhan adalah karya Allah.

\section{b. Pelayanan Kesembuhan Elia}

Elia adalah orang Tisbe, dari Tisbe-Gilead. Ia adalah seorang nabi Tuhan yang telah berani melawan raja Ahab dan Izebel, dengan mengatakan "Demi Tuhan yang hidup, Allah Israel, yang kulayani, sesungguhnya tidak akan ada embun atau hujan pada tahun-tahun ini, kecuali kalau kukatakan." (1 Raj. 17:1-2). Nubuatan nabi Elia ini sungguh menunjukkan keberaniannya untuk melawan raja Ahab.

la adalah juga seorang yang mengalami pemeliharaan Allah secara luar biasa mengagumkan. Karena nubuatannya itu, ia diperintahkan oleh Allah untuk pergi, dari hadapan Ahab, bersembunyi di tepi sungai kerit, di sebelah Timur sungai Yordan. la dapat minum dari sungai itu. Dan burung-burung gagak akan diutus oleh Allah untuk memberi makan kepadanya pada waktu pagi dan petang (ayat 3-6). Ini adalah pemeliharaan Allah yang pertama dari Allah, yaitu melalui sungai kerit dan burung gagak.

Setelah sungai itu kering, Tuhan juga telah menyediakan seorang janda di Sarfat yang akan memeliharanya. Karena itulah ia meninggalkan sungai itu dan berangkat ke Sarfat, yang adalah wilayah Sidon. Dan benar, melalui janda di Sarfat ini, Elia mengalami pemeliharaan Allah. Dimana pemeliharaan Allah nyata melalui materi yang berupa tepung di dalam tempayan dan minyak di dalam buli-buli yang tidak berkurang seperti yang telah difirmankan-Nya, (ayat 7-16). Ini adalah pemeliharaan Allah yang kedua, yang dialami Elia.

Selain Allah menyatakan pemeliharaan yang besar itu, Allah ternyata telah mengizinkan anak perempuan janda di Sarfat ini jatuh sakit. Bahkan sakitnya sangat 
keras, sehingga akhirnya meninggal. Pada waktu janda di Sarfat ini melihat anaknya jatuh sakit dan meninggal, ia telah mempertanyakan kedatangan Elia, sebagai abdi Allah. Inilah perkataan janda itu kepada Elia: "apakah maksudmu datang kemari, ya abdi Allah? Singgahkan engkauj kepadaku untuk mengingatkan kesalahanku dan untuk menyebabkan anakku mati?" (ayat 17-18). Tetapi pada akhirnya pemeliharaan Allah kembali terjadi, yaitu melalui pelayanan kesembuhan yang dilakukan Elia kepada anak perempuan janda di Sarfat ini.

Di dalam praktek pelayanan kesembuhan yang dilakukan Elia kepada seorang anak perempuan ini, yang ia lakukan adalah: meminta anak perempuan itu dari pangkuan ibunya, membawanya ke kamar atas, membaringkan di tempat tidurnya, lalu Elia berdoa kepada Allah. la juga mengujurkan badannya di atas anak itu sebanyak tiga kali dan terus berseru kepada Allah. Kemudian Tuhan mendengarkan permintaan Elia, sehingga nyawa anak itu pulang ke dalam tubuhnya. Anak itu hidup kembali (ayat 19-22). Inilah pelayanan kesembuhan Elia. Nabi Elia telah menyembuhkan seorang anak perempuan.

\section{c. Pelayanan Kesembuhan Elisa}

Nabi Elisa adalah seorang nabi yang dipilih oleh Elia untuk menggantikan dan meneruskan pelayanannya (2 Raj. 2:1-18). la sendiri adalah anak Safan, seorang pembajak. Ketika itu ia menerima ajakan Nabi Elia, dengan menangkap jubah Elia yang dilemparkannya kepadanya. Elisapun meninggalkan lembunya dan berlari mengikuti Elia. Pada waktu Elisa hendak mengikuti Elisa, ia meminta izin untuk mencium ayahnya dan ibunya. Tidak hanya itu, Elisa melakukan hal yang radikal, yaitu mengambil sepasang lembunya dan menyembelihnya. Bahkan bajaknyapun dipakainya sebagai kayu api. Lalu memberikan daging itu kepada orang-orangnya untuk dimakan. Kemudian ia mengikuti Elia dan menjadi abdinya (1 Raj. 19:19-21).

Praktek pelayaan kesembuhan Elisa berawal ketika ia menerima dan merasakan kebaikan dari suami-istri di Sunem. Di mana, di Sunem ada seorang perempuan kaya yang mengundang ia untuk singgah dirumahnya dan makan. Elisa menerima undangan ini beberapa kali. Sampai pada akhirnya perempuan sunem ini mengenali bahwa Elisa adalah abdi Allah, sehingga ia mengusulkan agar mereka membuatkan sebuah kamar khusus untuk Elisa (2 Raj.4:8-10). Atas kebaikan keluarga ini, Elisa memberi perintah kepada Gehazi untuk menanyakan hal atau perkara yang dapat Elisa perbuat kepadanya. mereka tidak ingin menyampaikan hal dan perkaranya. Tetapi, Gehazi sudah mengenal pergumulan mereka, bahwa mereka sudah tua, namun tidak memiliki seorang anak. Karena itu Elisa memberikan janji dan 
nubuatan, bahwa tahun depan, pada waktu yang sama mereka akan menggedong seorang anak (ayat 11-17). Maka terjadilah pada perempuan Sunem ini seperti yang dikatakan abdi Allah.

Tetapi, setelah anak perempuan ini besar, ia pun sakit dan kemudian mati (ayat 18-21). Karena itu, maka perempuan Sunem itu pergi untuk mencari dan menemukan Elisa, abdi Allah itu (ayat 22-24). Setelah bertemu Elisa, perempuan Sunem itu menyampaikan kekecewaannya kepada Elisa : "Adakah kuminta seorang anak lakilaki dari pada tuanku? Bukankah telah kukatakan : Jangan aku diberi harapan kosong? Dalam hal ini Elisa memberitahukan kepada Gahazi bahwa Allah telah menyembunyikan sesuatu. Karena ittu Gahazi diperintahkan untuk meletakkan tongkatnya di atas tubuh anak itu, supaya anak itu sembuh (ayat 25-29).

Tetapi perempuan Sunem bersumpah tidak akan meninggalkan Elisa, sehingga Elisa pada akhirnya ikut bersama-sama dengan perempuan ke rumahnya. Gahazi sudah melakukan apa yang diperintahkan kepadanya. Tetapi anak itu tetap tidak bangun. Kemudian Elisa masuk ke dalam kamar itu. la berdoa kepada Tuhan dan membaringkan tubuhnya di atas anak itu. Maka sembuhlah anak itu (ayat 30-38). Praktek pelayanan kesembuhan yang dilakukan Elisa, tidak hanya pada anak perempuan sunem (2 Raj. 4), tetapi juga terjadi pada Naaman (2 Raj. 5:1-17).

Dalam praktek pelayanan kesembuhan yang dilakukan Elisa kepada Naaman, sepertinya Elisa tidak melakukan suatu tindakan tertentu. Tetapi kesembuhan yang terjadi pada Naaman adalah akibat dari kepatuhan dan atau ketaatannya.

Disebutkan dalam kisah ini bahwa kesembuhan yang terjadi pada Naaman berawal ketika Naaman mendengar suatu kesaksian dari seorang perempuan Israel, yang menjadi tawanannya, dan yang bekerja pada istrinya. Demikianlah kesaksian gadis itu kepada nyonyanya : "sekiranya tuanku menghadap nabi yang ada di Samaria itu, maka tentulah nabi itu akan menyembuhkan dia dari penyakitnya." (2 Raj. 5:3). Terhadap kesaksian ini, Naaman meresponya dan menyampaikannya kepada raja, yang adalah pemimpinnya, mungkin dengan maksud dan tujuan untuk memohon izin dapat bertemu dengan nabi yang diceritakan perempuan Israel itu, yaitu nabi Elisa.

Selanjutnya, atas izin rajanya, Naaman benar-benar pergi dan datang ke Israel. Sesampainya Naaman di Israel, ia pada awalnya salah alamat. Karena yang dituju adalah raja Israel. Sehingga raja Israel menjadi marah (ayat 5-7). Tetapi hal ini telah didengar oleh nabi Elisa. Karena itu Elisa telah mengirimkan suatu pesan agar Naaman datang kepadanya, supaya ia tahu bahwa di Israel ada seorang nabi (ayat 8). Akhirnya Naaman pun datang ke rumah Elisa (ayat 9). 
Elisa melalui utusannya pada waktu itu memberikan perintah supaya Naaman pergi mandi tujuh kali dalam sungai Yordan, maka tubuhnya akan pulih kembali dan menjadi tahir (ayat 10). Mendengar perintah ini, Naaman menjadi gusar dan panas hati, sepertinya kecewa, karena tidak ditemui oleh nabi sebagaimana yang diceritakan kepadanya. Karena harapannya adalah ditemui oleh nabi itu, kemudian nabi itu berdoa kepada Tuhan dan melakukan suatu tindakan untuk menyembuhkan tubuhnya. Bahkan ia berpendapat bahwa sungai Abana dan Parpar, sungai-sungai Damsyik lebih baik dari sungai-sungai di Israel (ayat 11-12).

Tetapi karena nasehat para pegawai-pegawainya, bahwa perintah yang diberikan oleh nabi itu adalah perintah yang mudah, yaitu hanya untuk mandi, dibandingkan apabila mendapat perintah yang sukar, yang juga sementinya ia lakukan, maka Naaman pun mau melakukannya. Karena itu setelah ia turun dan membenamkan dirinya tujuh kali dalam sungai Yordan, sesuai dengan perkataan abdi Allah itu, pulihlah tubuhnya, seperti tubuh seorang anak dan ia menjadi tahir (ayat 1314).

Setelah ia sembuh, ia kembali kepada Elisa dan berkata : "Sekarang aku tahu, bahwa di seluruh bumi tidak ada Allah kecuali di Israel." Jadi, kesembuhan atas tubuhnya telah membuat Naaman mengakui Allahnya Israel.

\section{Pelayanan Kesembuhan di Perjanjian Baru}

Praktek pelayanan kesembuhan di dalam Perjanjian Baru sangat nyata dilakukan Tuhan Yesus. Mujizat-mujizat yang dilakukan Tuhan Yesus yang paling menonjol adalah mujizat kesembuhan orang dari sakit. Selain Tuhan Yesus, praktek pelayanan kesembuhan di dalam Perjanjian Baru juga dilakukan para rasul, baik oleh rasul Petrus dan Yohanes, serta Paulus.

\section{a. Pelayanan Kesembuhan Tuhan Yesus}

Di dalam Perjanjian Baru, khususnya Kitab-kitab Injil, ada begitu banyak kisah atau cerita-cerita mujizat kesembuhan yang dilakukan Tuhan Yesus. Tuhan Yesus telah menyembuhkan: orang yang sakit kusta (Mark. 1:40-45); orang yang tuli (Mark. 7:31-37); orang yang bisu (Mark. 9:14-29); dll. Salah satu pelayanan kesembuhan yang dilakukan Tuhan Yesus yang kita perhatikan di sini adalah kesembuhan yang dialami oleh Bartimeus (Markus 10:46-52).

Pelayanan kesembuhan yang dialami oleh Bartimeus terjadi ketika Tuhan Yesus dan murid-murid-Nya tiba di Yerikho. Dan ketika la keluar dari Yerikho bersama dengan murid-murid-Nya dan orang banyak yang berbondong-bondong, Bartimeus 
yang sakit buta, mendengar bahwa Yesus lewat, ia berseru-seru: "Yesus, Anak Daud, kasihanilah aku!" (ayat 47-48). Kemudian, Yesus bertanya kepadanya: "Apa yang kau kehendaki supaya Aku perbuat bagimu?" Jawab Bartimeus: "Rabuni, supaya aku dapat melihat!" Lalu kata Tuhan Yesus kepadanya: "Pergilah, imanmu telah menyelamatkan engkau!" Pada waktu itu juga melihatlah Bartimeus.

Di dalam kisah kesembuhan ini, pada awalnya ketika Bartimeus berseru kepada Tuhan Yesus, ada banyak orang yang mendengar seruannya, mereka menegurnya dan meminta supaya ia diam. Tetapi, ketika ia diminta untuk diam, Bartimeus justru semakin keras di dalam berseru kepada Yesus. Sehingga Tuhan Yesus berhenti dan berkata kepada murid-murid-Nya: "Panggilah dia!" Lalu terjadilah dialog antara Tuhan Yesus dengan bartemeus, dan kesembuah juga terjadi atasnya.

Praktek pelayanan kesembuhan yang dialami Bartimeus terjadi karena: Pertama, iman Bartemeus kepada Yesus, Anak Daud. Sebagaimana ia tahu bahwa Yesus orang Nazaret sanggup menyembuhkan orang sakit, maka ia pun berseru-seru kepada-Nya memohon belas kasihan dan kesembuhan atas matanya, sehingga ia dapat melihat lagi. Kedua, Tuhan Yesus mau atau berkenan memberikan kesembuhan kepada-Nya. Tuhan Yesus melihat bahwa imannya jugalah yang menyelamatkan.

\section{b. Pelayanan Kesembuhan rasul Petrus dan Yohanes}

Praktek pelayanan kesembuhan yang dilakukan rasul Petrus dan Yohanes dikisahkan di dalam kitab Kisah Para Rasul (Kis. 3:1-10).

Kisahnya adalah bahwa pada saat itu rasul Petrus dan Yohanes sedang dalam perjalanan menuju Bait Allah untuk beribadah, pada suatu petang. Dimana, disitu ada seorang laki-laki, yang lumpuh sejak lahirnya sehingga ia harus diusung. Tiap-tiap hari orang itu diletakkan dekat pintu gerbang Bait Allah, untuk meminta sedekah kepada setiap orang yang masuk ke Bait Allah. Ketika orang itu melihat, bahwa rasul Petrus dan Yohanes hendak masuk ke Bait Allah, ia meminta sedekah. Lalu mereka menatap orang lumpuh itu dan Petrus berkata : "Lihatlah kepada kami”. Emas dan perak tidak ada padaku, tetapi apa yang kupunyai kuberikan kepadamu (kata Petrus) : Demi Nama Yesus Kristus, orang Nazaret itu, berjalanlah!" Lalu Petrus memegang tangan kanan orang itu dan membantu dia berdiri. Seketika itu juga kuatlah kami dan mata kaki orang itu (ayat 1-7).

Dampak dari kesembuhan ini sangat luar biasa. Bagi orang yang disembuhkan, pengalaman ini adalah pengalaman yang sangat baru dan penting. Karena itu, ia melonjak berdiri, lalu berjalan kesana-kemari. la juga mengikuti mereka ke dalam Bait 
Allah. la berjalan dan melompat sambil memuji Allah (ayat 8). Ini adalah pengalaman pertama karena memang sejak ia lahir, ia sudah sakit lumpuh.

Dampak pelayanan kesembuhan ini juga dialami oleh banyak orang yang melihat dan menyaksikan peristiwa ini. Mereka yang melihat peristiwa ini juga ikut memuji Allah. mereka ikut memuji Allah karena heran dan takjub melihat tanda dan mujizat yang ajaib, yang telah terjadi di tengah-tengah mereka.

Melihat atau mencermati praktek pelayanan kesembuhan dan dampaknya, kita dapat memetik suatu pelajaran bahwa kesembuhan yang dialami oleh seseorang, adalah karena kuasa nama Tuhan Yesus dan untuk puji-pujian Bagi Allah. Apakah itu bagi seseorang yang dipakai Tuhan untuk menyatakan kuasa kesembuhan-Nya, apakah itu bagi orang yang telah disembuhkan dan bagi orang banyak atau masyarakat yang menyaksikannya, semestinya semakin dapat mengagumi kuasa Allah, serta memuji nama-Nya.

Jadi, praktek pelayanan kesembuhan sesungguhnya telah dilakukan oleh para rasul. Dalam hal ini kesembuhan yang dialami oleh banyak orang merupakan pelayanan kesembuhan yang dinyatakan Allah melalui rasul-rasul-Nya. Juga merupakan bukti bahwa Allah senantiasa menyertai pelayananan mereka. Praktek pelayanan kesembuhan memang telah dipercayakan kepada para rasul dan kepada setiap orang percaya, karena kesembuhan itu bersumber dari kuasa Allah atau kuasa Nama Yesus Kristus, orang Nazaret itu.

\section{c. Pelayanan Kesembuhan rasul Paulus}

Paulus sebagai rasul Tuhan Yesus yang paling terakhir, sepertinya tidak banyak melakukan praktek pelayanan kesembuhan. Tetapi bukan berarti bahwa rasul Paulus tidak pernah sama sekali berdoa untuk kesembuhan orang sakit dan melaluinya kuasa Allah tidak dinyatakan. Karena di dalam Kisah Para Rasul, Paulus memang pernah berdoa untuk kesembuhan orang sakit, yaitu ayah Gubernur pulau Malta (Kis. 28: 8), bahkan pernah dipakai Tuhan untuk membangkitkan orang mati, yaitu Eutikhus (Kis. 20:9-10).

Di dalam kisah pelayanan kesembuhan ayahnya Publius, yang dikisahkan kitab Kisah Para Rasul 28, yang menarik adalah bahwa kesembuhan yang terjadi pada ayah Gubernur pulau Malta ini didahului suatu peristiwa yang sangat tragis. Peristiwaperistiwa yang tragis itu adalah, pertama, rasul Paulus mengalami karam kapal dan diselamatkan, sebelum akhirnya sampai ke pulau Malta (Kis. 27:14-44). Kedua, rasul Paulus sesampainya di pulau Malta ternyata mengalami kejadian digigit ular beludak (Kis. 28:1-6). 
Melalui peristiwa-peristiwa yang tragis ini, sesungguhnya pelayanan kesembuhan yang terjadi pada ayah Publius, Gubernur pulau Malta menjadi peristiwa yang sangat penting dan berharga. Artinya, untuk suatu kesembuhan bagi satu orang saja, Allah telah mengizinkan perkara-perkara di atas terjadi dan menyertai Paulus.

Pada praktek pelayanan kesembuhan yang dilakukan rasul Paulus pada ayah Gubernur pulau Malta, yang sedang sakit demam dan desentri, rasul Paulus masuk ke dalam kamarnya, berdoa, menumpangkan tangannya atas tubuhnya dan menyembuhkan dia (Kis. 28:7-8).

Dan praktek pelayanan kesembuhan yang dilakukan Paulus di Pulau Malta bukan hanya tertuju pada satu orang saja. Tetapi setelah peristiwa kesembuhan atas ayahnya Publius, ada banyak orang yang datang kepadanya untuk disembuhkan. Dengan demikian pelayanan Paulus di sana dapat diterima dengan baik (Kis. 28:9).

Di sini, apa yang dilakukan rasul Paulus di dalam menyembuhkan seseorang sangat jelas. Artinya, apa yang dilakukan Paulus di dalam praktek pelayanan kesembuhan dapat dengan mudah dicontoh dan atau dipraktekkan.

Pelayanan kesembuhan yang dialami oleh seseorang sesungguhnya dapat menjadikan pelayanan kita dapat dialami dan dirasakan masyarakat pada umumnya. Apakah mereka itu seiman dengan kita atau tidak? Pelayanan kesembuhan ini benarbenar dapat dilakukan setiap orang percaya dan juga gereja. Sehingga melalui pelayanan kesembuhan yang kita dan gereja lakukan, banyak orang yang disembuhkan dapat merasakan dan mengalami kuasa dan kebaikan Allah atas manusia berdosa.

\section{Pelayanan Kesembuhan Menurut Para Ahli}

Sembuh atau kesembuhan merupakan hasil yang dicapai dari pelayanan kesembuhan atau terlaksananya fungsi pastoral menyembuhkan. Karena menurut William A. Clebsch dan Charles R. Jaekle, salah satu fungsi pastoral yang telah dilakukan disepanjang sejarah gereja adalah menyembuhkan (healing) (Clebsch \& Jaekle, 1967). Itu artinya bahwa bila fungsi-fungsi pastoral, terutama fungsi menyembuhkan dilaksanakan, maka akan menghasilkan kesembuhan.

Selanjutnya, menurut Howard Clinebel menyembuhkan (healing) adalah "Suatu fungsi pastoral yang terarah untuk mengatasi kerusakan yang dialami orang dengan memperbaiki orang itu menuju keutuhan dan membimbingnya ke arah kemajuan di luar kondisinya terdahulu" (Clinebel, 2006). Tentu yang dimaksudkan Clinebel tentang kesembuhan bukan hanya kesembuhan secara fisik saja, tetapi juga psikis dan 
bahkan aspek yang lain. Karena bagi Clinebel, sebagaimana tambahan 1 fungsi pastoral yaitu fungsi memelihara atau mengasuh (nurturing), kesembuhan berarti kesembuhan jiwa (Clinebel, 2006). Hal ini didasarkan bahwa pada abad-abad permulaan gereja, "penyembuhan jiwa" (cure of soul) kadang-kadang dipahami sebagai menyembuhkan dan juga sering dipahami sebagai memelihara atau mengasuh.

Menurut Emmanuel Y. Lartey, tugas penyembuh pastoral itu adalah keterbukaan dan perhatian. Penyembuh pastoral mendengarkan secara mendalam keluhan dan erangan dari manusia dalam kesusahannya (Lartey, 2003). Konteks lokal dan sosial pelayanan Lartey memungkinkan ada banyak orang yang terlibat pelayannan kesembuhan ini, yaitu ikut terlibat dalam mendengarkan keluhan dan erangan dari masyarakatr yang sedang mengalami sakit, susah dan menderita. Karena itu penyembuh dalam konteks ini tidak selalu dokter atau tim medis.

Sedangkan menurut Aart Van Beek, dalam pendampingan pastoral, fungsi menyembuhkan ini penting dalam arti bahwa melalui pendampingan yang berisi kasih sayang, rela mendengarkan segala keluhan batin dan kepedulian yang tinggi akan membuat seseorang yang menderita mengalami rasa aman dan kelegaan sebagai pintu masuk ke arah penyembuhan yang sebenarnya (Beek, 2010). Dalam hal ini Van Beek memang mengkaji bahwa kesembuhan itu holistik yang meliputi aspek fisik, psikis atau mental, sosial dan spiritual. Dengan demikian, maka pelayanan kesembuhan itu benar-benar penting dan mendedsak untuk dilakukan mengingat angka kasus orang terpapar virus corona ini terus meningkat.

\section{Pelayanan Kesembuhan yang Mendesak pada Masa Kini}

Masa kini adalah masa sekarang. Di Indonesia, masa kini dapat disebut sebagai masa transisi menuju Indonesia baru. Menurut Daniel Susanto, setelah Orde Baru tumbang, Indonesia memasuki masa transisi untuk menuju Indonesia Baru (D. Susanto, 2006). Selanjutnya, Daniel Susanto menyebutkan bahwa pada masa transisi seperti ini masih terdapat banyak persoalan yang menghadang. Dan salah satu persoalan, dari delapan persoalan yang ia sebutkan, yang membutuhkan tanggapan pastoral adalah persoalan ketujuh, yaitu tentang stres dan gangguan mental (D. Susanto, 2006). Dalam hal ini, konteks masa kini yang disebutkan Daniel Susanto tentu menunjuk pada waktu sebelum adanya pandemi yang melanda Indonesia.

Selama ini gereja tentu sudah melakukan suatu tindakan sebagai tanggapan pastoral terhadap berbagai persoalan yang memang membutuhkan tanggapan 
pastoral. Terutama terhadap persoalan stres dan gangguan mental atau terhadap jemaat yang sedang sakit dan memiliki berbagai persoalan. Hanya saja, pelayanan pastoral yang dilakukan gereja-gereja kita di Indonesia pada masa kini, dapat dikatakan sempit dan terbatas. Menurut Daniel Susanto, pelayanan pastoral yang sempit yaitu pelayanan diarahkan kepada orang-orang selaku individu atau kelompok kecil (misalnya keluarga), dan tidak terbuka kepada masyarakat. Dan pelayanan pastoral yang terbatas, yaitu pelayanan yang ditujukan pada anggota gereja (D. Susanto, 2006). Karena sempit dan terbatasnya pelayanan gereja sebagaimana yang disebutkan Daniel Susanto di atas, maka gereja atau warga gereja tentu belum depat melakukan pelayanan kepada masyarakat yang lebih luas.

Terhadap persoalan stres dan gangguan mental, serta terhadap orang-orang yang sedang sakit, susah dan menderita karena pandemi covid 19 ini, gereja memang dipanggil untuk melakukan pelayanan kesembuhan. Pelayanan kesembuhan yang mendesak pada masa kini seperti apakah, yang perlu dilakukan oleh gereja? Pelayanan kesembuhan di masa pandemi covid 19 yang dapat dilakukan oleh gereja pada masa kini tentu pelayanan kesembuhan yang sudah dicontohkan oleh Alkitab, baik itu di dalam Perjanjian Lama, maupun di Perjanjian Baru, serta pelayanan kesembuhan sebagaimana yang diusulkan oleh para ahli yang secara serius melakukan pelayanan kesembuhan.

Karena itu pelayanan kesembuhan di masa pandemi covid 19 yang dapat dilakukan oleh gereja pada masa kini adalah pelayanan kesembuhan yang dicontohkan Alkitab dan pelayanan kesembuhan sebagaimana yang diusulkan oleh para ahli.

\section{Pelayanan kesembuh berdasarkan Alkitab}

Berdasarkan teks-teks Alkitab, baik dalam Perjanjian Lama (PL) maupun dalam Perjanjian Baru (PB) di atas, sesungguhnya pelayanan kesembuhan merupakan sebuah pelayanan yang Alkitabiah dan aktual, serta relevan untuk terus dilakukan hingga masa kini. Terlebih di saat pandemi sedang melanda negara kita Indonesia sejak awal 2020. Bagaimana pandangan Alkitab tentang pelayanan kesembuhan ini dapat dilakukan pada masa kini? Pertama, dengan cara mendoakan (berdoa) dan memohonkan berkat pengampunan. Di dalam Alkitab disebutkan bahwa salah satu penyebab orang menjadi sakit dan menderita adalah karena dosa-dosa dan pelanggarannya. Karena itu, sebagaimana Musa telah berdoa dan memohonkan anugerah pengampunan, maka kemudian Miryam menjadi sembuh. Maka dalam hal 
ini, ketika ada banyak orang yang sedang sakit, susah dan menderita, mereka pada dasarnya memerlukan doa dan anugerah pengampunan untuk kesembuhan mereka. Pertama-tama kesebuhan fisik, terlebih kesembuhan spiritual, yaitu relasai mereka dengan Tuhan. Kedua, dengan beriman dan percaya penuh kepada kuasa Allah. Iman yang teguh menjadi dasar yang penting bagi pelayan-pelayan kesembuhan. Sebagaimana nabi Elia dan Elisa, para pelayan kesembuhan pada masa kini perlu belajar untuk memiliki iman dan percaya yang teguh kepada Allah. Dengan keyakinan yang penuh kepada kuasa Allah, maka perkara-perkara besar dan ajaib akan terjadi. Melalui iman dan percaya yang teguh dari pelayan-pelayan kesembuhan, orang-orang yang sedang sakit, susah dan menderita, khususnya yang terpapar corona dapat belajar beriman dan percaya penuh kepada Tuhan. Dengan iman dan percaya penuh, orang-orang yang sakit dapat tetap kuat menghadapi dan menjalani masa-masa sulit saat isolasi mandiri maupun pada masa-masa menunggu pemulihan. Ketiga, dengan berserah dan belajar memahami rencana yang baik dari Allah. Melalui pelayanan kesembuhan dalam Perjanjian Baru, khususnya yang dilakukan oleh Tuhan Yesus, keadaan sakit, sudah dan menderita tidak selalu disebakan dosa-dosa mereka atau orang tua mereka, tetapi melalui peristiwa-peristiwa seperti sakit, kesusahan dan penderitaan kuasa Allah akan dinyatakan dan Allah dipermuliakan. Pemahaman yang demikian ini perlu dimiliki oleh para pelayan kesembuhan dan orang-orang yang sedang sakit. Dengan demikian, selama mereka sedang sakit, susah dan menderita, serta menantikan kesembuhan, mereka dapat berfikir positif, tetap dapat bersyukur dan memuji-muji Tuhan. Hal inilah yang sesungguhnya akan menjadi obat yang manjur, sebagaimana firman-Nya "hati yang gembira adalah obat yang manjur" (Ams. 17:22). Keempat, dengan kesetiaan. Orang-orang yang sedang sakit, susah dan menderita bisa jadi tidak akan sembuh di dunia sampai ajal tiba. Tetapi, orang-orang percaya dipanggil untuk setia sampai akhir. Itu artinya bahwa ada orang-orang yang tidak mengalami kesembuhan di dunia, tetapi mereka akan mendapat kesembuhan kekal.

\section{Pelayanan Kesembuhan berdasarkan pemikiran para Ahli.}

Sebagaimana sudah disebutkan oleh para ahli di atas bahwa pelayanan kesembuhan itu penting dan mendesak untuk dilakukan sepanjang sejarah gereja, pada masa pandemi covid 19 ini pelayanan kesembuhan ini juga perlu dilakukan oleh gereja. Bagaimana menurut para ahli pelayanan kesembuhan ini dilakukan pada masa kini? Pertama, gereja atau orang-orang yang terpanggil untuk melakukan pelayanan 
kesembuhan dapat melakukan pelayanan pendampingan bagi orang-orang yang sedang sakit terpapar virus corona dengan bentuk pemberian pelayanan diakonia atau pelayanan kasih. Orang-orang yang sedang sakit terpapar virus corona pada saat ini banyak yang dirawat di rumah sakit, tetapi juga banyak yang melakukan isolasi mandiri. Orang-orang yang sedang sakit terpapar virus corona, yang dirawat di rumah sakit, secara umum adalah orang-orang yang memiliki keluhan atau rasa sakit yang sangat serius, seperti sesak nafas. Karena itu, terhadap mereka para pelayan kesembuhan sepertinya tidak bisa berbuat apa-apa. Tetapi sesungguhnya tidaklah demikian. Para pelayan kesembuhan tetap dapat menopang di dalam doa dan menguatkan keluarga, yang tentu sedang mengalami kesusahan. Tetapi terhadap orang-orang yang sedang sakit dan menjalani isolasi mandiri, para pelayanan kesembuhan dapat melakukan banyak hal, seperti memberikan makanan dan minuman ringan, menyediakan vitamin, memberikan pelayanan pendampingan melalui telepon, atau pesan-pesan singkat dan bahkan melalui fasilitas video call. Dengan pelayanan kesembuhan yang demikian, mereka yang sakit, susah dan menderita dikuatkan, ditopang dan disembuhkan.

Kedua, gereja atau orang-orang yang terpanggil untuk melakukan pelayanan kesembuhan dapat melakukan pelayanan pendanpingan bagi orang-orang yang sedang sakit terpapar virus corona dengan melakukan pelayanan perkunjungan yang kontinu. Pada masa covid 19 ini, pemerintah memang sudah memberlakukan adanya prokes, salah satunya menjaga jarak. Namun demikian, bukan berarti pelayanan perkunjungan tidak dapat dilakukan. Pelayan kesembuhan melalui perkunjungan kepada orang-orang yang sedang sakit terpapar virus corona tetap dilakukan ke rumah-rumah atau ditempat-tempat isolasi mandiri dengan tetap menjaga jarak, atau berkunjung dengan tidak terlalu dekat. Tetapi melalui pelayanan perkunjungan, orangorang yang sedang sakit dan sedang menjalani masa isolasi mandiri tetap dapat merasakan perhatian dan kehadiran dari saudara-saudara seiman atau masyarakat yang masih peduli kepada mereka. Dengan demikian, mereka tidak merasakan sendirian.

Ketiga, gereja atau orang-orang yang terpanggil untuk melakukan pelayanan kesembuhan dapat melakukan pelayanan pendanpingan bagi orang-orang yang sedang sakit terpapar virus corona dengan melakukan pelayanan konseling pastoral. Tidak menutup kemungkinan bahwa orang-orang yang menjalani isolasi mandiri selama 14 hari, bahkan ada yang memerlukan waktu lebih lama lagi hingga 47 hari mengalami stress tingkat tinggi dan depresi. Karena itulah mereka membutuhkan 
pelayanan kesembuhan melalui konseling pastoral. Oleh karnea itu gereja atau orangorang yang terpanggil untuk melakukan pelayanan kesembuhan dapat memberikan pelayanan konseling pastoral. Dalam hal pelayanan konseling pastoral ini, sedapat mungkin dilakukan oleh orang-orang yang terlatih. Karena itu gereja perlu memiliki relasi-relasi dengan orang-orang yang memiliki pengalaman melakukan pelayanan konseling pastoral.

Keempat, gereja atau orang-orang yang terpanggil untuk melakukan pelayanan kesembuhan dapat melakukan pelayanan pendanpingan bagi orang-orang yang sedang sakit terpapar virus corona dengan melakukan pelayanan penghiburan atau penopangan. Dalam hal ini, Daniel Susanto, menyatakan bahwa fungsi menopang dalam pelayanan pastoral di Indonesia saat ini dapat dilakukan bagi orang-orang sakit, yang secara medis tidak dapat disembuhkan lagi, bagi orang-orang yang berduka karena kematian dan bagi orang-orang menderita (Daniel Susanto, 2013). Hal ini diperlukan, karena orang-orang yang terpapar virus korona tentu mendengar bahwa ada begitu banyak orang yang sudah meninggal dunia karena virus ini. Bukan hanya itu saja, bahkan tidak menutup kemungkinan bahwa salah satu anggota keluarga mereka memang sudah ada yang meninggal dunia. Dalam hal ini, mereka membutuhkan kata-kata penghiburan dan pendampingan di saat-saat tertentu ketika mereka sedang dalam menjalani isolasi mandiri.

Kelima, gereja atau orang-orang yang terpanggil untuk melakukan pelayanan kesembuhan dapat melakukan pelayanan pendanpingan bagi orang-orang yang sudah sembuh dari sakit terpapar virus corona dengan melakukan pelayanan kesembuhan jiwa, yaitu melaui perwujudan fungsi memelihara atau mengasuh (nurturing). Sebagaimana konsep kesembuhan yang diusulkan oleh para ahli, yaitu kesembuhan yang holistik, yang meliputi berbagai aspek, yaitu fisik, psikis atau m,ental, sosial dan spiritual, maka pelayanan kesembuhan itu perlu kontitu, tidak selesai hanya ketika orang yang sakit terpapar virus corona tidak lagi menunjukkan gejala, tetapi sampai mereka memiliki gaya hidup yang baru, dan terus mengalami pertumbuhan.

\section{KESIMPULAN}

Pelayanan kesembuhan di tengah-tengah jemaat dan masyarakat pada saat ini merupakan pelayanan pastoral yang sangat penting dan mendesak untuk dipikirkan dan dikerjakan dengan serius dan dengan tepat. Seperti halnya Tuhan Yesus, la sangat peduli dan memperhatikan orang-orang yang sakit, susah dan menderita, 
sehingga la menjamah dan menyembuhkannya. Pelayanan kesembuhan sebagai bagian yang utuh dari pelayanan pastoral harus dilakukan oleh gereja secara kontinu. Artinya, gereja tidak boleh mengelak atau menolak pelayanan ini, melainkan mencari dan menemukan pola-pola atau cara-cara yang lebih transformatif lagi. Dengan demikian pelayanan gereja benar-benar berdampak bagi jemaat dan masyarakat dan Nama Tuhan dipermuliakan.

Demikilah artikel ini dibuat dalam rangka turut memikirkan atau menghasilkan suatu refleksi teologis bagi perkembangan pelayanan pastoral khususnya bagi pelayanan kesembuhan di dalam gereja-gereja di Indonesia pada masa kini.

\section{DAFTAR PUSTAKA}

Abineno, J. L. C. (1994). Pelayanan Pastoral Kepada Orang Sakit. BPK Gunung Mulia.

Beek, A. Van. (2010). Pendampingan Pastoral. BPK Gunung Mulia.

Clebsch, W., \& Jaekle, C. R. (1967). Pastoral Care in Historical Perspective. Harper \& Row Publisher.

Clinebel, H. (2006). Tipe-Tipe Dasar Pendampingan dan Konseling Pastoral. BPK Gunung Mulia.

Daniel Susanto (Ed.). (2003). Bunga Rampai Teologi dan Pelayanan Pastoral, Buku kenang-kenangan 25 tahun Pelayanan Pendeta Daniel Susanto di GKI Menteng. Majelis Jemaat GKI Menteng.

Detiknews. (2020). Kapan sebenarnya Corona Pertama Kali Masuk RI?

Detiknews. (2021). Kasus baru tembus 47.791, ini data lengkap Corona RI.

Lartey, E. Y. (2003). In Living Color An Intercultural Approach to Pastoral Care and Counseling. Jessica Kingsley Publishers.

Susanto, D. (2006). Pelayanan Pastoral di Indonesia Pada Masa Transisi, Orasi Dies Natalis ke 72 STT Jakarta. UPI STT Jakarta.

Susanto, D. (2013). Kapita Selekta dan Pelayanan Pastoral, Buku kenang-kenangan

35 tahun Pelayanan Pendeta Daniel Susanto di GKI Menteng. Majelis Jemaat GKI Menteng.

Wiryasaputra, T. S. (2016). Pendampingan Pastoral Orang Sakit. Kanisius. 